\title{
PENGEMBANGAN MODEL PEMBELAJARAN GUIDIF (GUIDED DISCOVERY DENGAN MEDIA INTERAKTIF) DALAM MENINGKATKAN HASIL BELAJAR IPA SD
}

\author{
Yulius Kristini' ${ }^{1}$, Henny Dewi Koeswati ${ }^{2}$, Sri Giarti ${ }^{3}$ \\ 1Pendidikan Guru Sekolah Dasar, Universitas Kristen Satya Wacana yuliuskristini13@gmail.com , \\ 2Pendidikan Guru Sekolah Dasar, Universitas Kristen Satya Wacana dewi@staff.uksw.edu \\ 3Pendidikan Guru Sekolah Dasar, Universitas Kristen Satya Wacana sgiarty@gmail.com
}

\section{INFO ARTIKEL \\ Riwayat Artikel: \\ Diterima: $24-03-2018$ \\ Disetujui: 09-04-2018}

\section{Kata Kunci:}

Guidif,

Hasil Belajar,

IPA

\section{A. LATAR BELAKANG}

Menurut Permendikbud (2006), Trianto (2013:136) dan Ahmas Susanto (2013:167) menyatakan bahwa IPA merupakan suatu kumpulan teori yang sistematis dengan cara mencari tahu tentang alam semesta melalui model pembelajaran ilmiah seperti observasi dan eksperimen serta menuntut sikap ilmiah seperti rasa ingin tahu, terbuka, jujur sehingga mendapat suatu penemuan dan kesimpulan. Pembelajaran IPA harus dirancang dan dilaksanakan sesuai dengan "SALINGTEMAS" (Sains, lingkungan, teknologi dan masyarakat) sehingga dapat menumbuhkan keterampilan proses, sikap ilmiah dan hasil belajar.

Berdasarkan simpulan di atas, guru dituntut untuk merancang dan melaksanakan pembelajaran, guru juga harus memiliki kompetensi dalam memanfaatkan teknologi informasi dan komunikasi dalam kegiatan pembelajaran. Hal ini sejalan dengan Permendiknas No 16 Tahun 2007 yang menyatakan tentang standar kualifikasi akademik dan kompetensi guru yang menyebutkan ada empat kompetensi yaitu kompetensi pedagodik, kompetensi professional, kompetensi sosial dan kompetensi kepribadaian. Dari keempat kompetensi tersebut kompetensi yang berhubungan dengan memanfaatkan teknologi informasi dan komunikasi dalam kegiatan pembelajaran ialah pedagogik dan kompetensi professional. Pada kompetensi pedagogik disebutkan bahwa salah satu kompetensinya guru memanfaatkan teknologi informasi dan komunikasi untuk kepentingan penyelenggaraan kegiatan pengembangan yang mendidik; sedangkan kompetensi profesional menyatakan bahwa salah satu kompetensi guru adalah memanfaatkan teknologi informasi dan komunikasi untuk berkomunikasi dan mengembangkan diri.

Berkaitan dengan pembelajaran IPA dan kompetensi guru, guru harus merancang pembelajaran yang sesuai dengan pembelajaran berbasis TIK. Artinya, didalam pembelajaran guru harus memanfaatkan TIK sebagai sumber belajar. Sehingga pengunaan media pembelajaran dapat menarik siswa dalam pembelajaran IPA di kelas. Sejalan dengan pendapat Azhar Arsyad (2011:2) media pembelajaran merupakan sebagai media 
yang dapat digunakan untuk membangkitkan motivasi siswa dalam belajar dan merangsang kegiatan belajar.

Berdasarkan hasil observasi dan wawancara yang telah dilakukan di SDN 01 Anggrasmanis pada kelas 3, guru terlihat belum menggunakan metode pembelajaran bervariasi yang sesuai dengan rambu-rambu pembelajaran IPA, guru cenderung menggunakan metode ceramah, tanya jawab dan diskusi. Guru belum menggunakan teknologi informasi dan komunikasi (TIK) sebagai media pembelajaran. Dari beberapa permasalahan yang diajarkan berdampak pada hasil belajar siswa khususnya muatan IPA. Hasil belajar yang diperoleh siswa banyak yang dibawah KKM (Kriteria Ketuntasan Minimal). KKM yang diterapkan pada mata pelajaran IPA di SD ini adalah 70. Hasil belajar yang kurang itu terbukti dari total siswa yaitu 23 siswa hanya terdapat 9 siswa yang tuntas KKM atau sebanyak 39,12\%. Sehingga sebanyak 14 siswa yang tidak lulus KKM atau sebanyak 60,86\%. Tentunya, hal seperti ini bukan yang diharapkan oleh siapapun termasuk guru, siswa, sekolah dan juga orang tua.

Berdasarkan permasalahan di atas, menunjukkan bahwa pembelajaran selama ini belum dilakukan secara efektif. Seharusnya guru menggunakan model pembelajaran yang sesuai rambu-rambu pembelajaran IPA. Selain itu, guru juga menggunakan media pembelajaran sebagai alat bantu pembelajaran, sehingga dapat menarik perhatian dan minat siswa. Keadaan ini akhirnya berdampak pada hasil belajar siswa. Oleh karena itu peneliti ingin menutup kesenjangan antara kondisi ideal dan kondisi lapangan. Untuk menguragi kesenjangan dan menutup kondisi tersebut penulis mengembangkan produk berupa model pembelajaran ilmiah berbasis TIK yaitu model pembelajaran Guidif. Model ini berpotensi dapat meningkatkan hasil belajar IPA. Model pembelajaran Guidif merupakan model pembelajaran guided discovery yang dikemas dengan menggunakan software Adobe Flash $\mathrm{CS}_{3}$ yang berisi tentang animasi, gerak, suara yang dapat dikemas menjadi media interaktif yang memiliki beberapa pilihan dalam menu awal berupa materi, gambar, soal dan game.

Berpijak pada kesenjangan dan kebutuhan di atas, dibutuhkan model pembelajarn yang mampu menyajika pembelajarn yang berwawasan luas, mendalam, serta mampu melatih siswa untuk menemukan pengetahuannya sendiri. Model pembelajarn yang mampu menyajikan pembelajarn seperti itu salah satunya adalah model pembelajaran Guided Discovery. Abrani Nur Aan (2012:46) menjelaskan Guided Discovery merupakan metode pembelajaran yang mengarahkan siswa pada kegiatan yang dapat mengembangkan keterampilan proses sains di mana siswa dibimbing untuk menemukan dan menyelidiki sendiri tentang suatu konsep sains sehingga pengetahaun dan keterampilan yang dimiliki siswa bukan hasil mengingat melainkan temuan siswa sendiri.
Di samping itu, untuk dapat mengembangkan kreativitas dan ketertarikan siswa untuk belajar perlu dikembangkan media dengan memanfaatkan TIK. Musfiqon (2012:86) mendefinisikan bahwa media pembelajaran sebagai sebuah alat bantu berupa fisik maupun non fisik yang sengaja digunakan sebagai perantaran antara guru dan siswa dalam memahami materi pembelajaran agar lebih efektif dan efisien, sehingga materi pembelajaran lebih cepat diterima siswa dengan utuh serta menarik minat siswa untuk belajar lebih lanjut.

Berdasarkan paparan di atas, dapat diperoleh solusi yaitu dengan mengembangkan antara model pembelajaran Guided Discovery dengan media interaktif yang memanfaatkan TIK, khususnya materi Gerak Benda untuk siswa kelas 3. Kemudian dalam mengembangkan produk berupa media ini perlu menggunakan model pengembangan. Model pengembangan yang cocok untuk mengembangkan yaitu model ASSURE.

Sesuai dengan uraian diatas, maka tujuan dalam penelitian ini adalah 1) Mengembangan model pembelajaran Guidif dalam meningkatkan hasil belajar IPA kelas 3. 2) Mengetahui seberapa tingkat validitas produk model pembelajaran Guidif dalam meningkatkan hasil belajar IPA kelas 3. 3) Mengetahui efektivitas pembelajaran Guidif dalam meningkatkan hasil belajar IPA SD.

\section{B. METODE PENELITIAN}

Penelitian ini dilakukan dengan menggunakan jenis Penelitian dan Pengembangan atau Research \& Development ( $R \& D)$. Menurut Sukmadinata (2015:164) Penelitian dan Pengembangan atau $R \& D$ merupakan suatu proses atau langkah-langkah untuk mengembangkan suatu produk baru atau penyempurnaan produk yang telah ada, yang dapat dipertangggungjawabkan. Penelitian ini akan dilakukan berdasarkan tahapan penelitian dan pengembangan dari Mawardi (2014:3) yaitu studi pendahuluan, desain dan pengembangan, dan pengujian. Akan tetapi, penelitian ini hanya sampai dengan tahap ke dua yaitu desain dan pengembangan saja. Penelitian ini dilakukan kepada siswa kelas 3 SDN o1 Anggrasmanis Kabupaten Karanganyar.

Prosedur dalam penelitian ini melalui dua tahap yaitu: (1) studi pendahuluan dan (2) desain dan pengembangan. Pada studi pendahuluan akan dilakukan analisis kebutuhan mengguakan instrumen wawancara dan studi dokumentasi hasil belajar. Tahap selanjutnya yaitu desain dan pengembangan dengan draf awal meliputi: 1) memilih mata pelaj aran; 2) melakukan analisis SKL, standar kompetensi, kompetensi dasar serta indikator; 3) membuat RPP dan Silabus; 4) merancang konten yang berkaitan dengan media; 5) merancang media; 6) membuka aplikasi adobe flash $\mathrm{CS}_{3}$; 7) memilih tampilan awal dalam media yang digunakan; 
8) membuat menu-menu yang terdapat dalam media interaktif; 9) memilih gambar yang akan digunakan dalam media; 10) menambahkan animasi pada gambar dalam media; 11) memasukkan materi dalam media; 12) memasukkan soall dalam media; 13) menentukan skor untuk untuk jawaban yang salah dan jawaban yang benar; 14) membuat game yang terdapat dalam media; 15) mendesain game agar sesuai dengan kebutuhan siswa yang berkaitan dengan materi.

Setelah diperoleh draf awal Model Pembelajaran Guidif yang dilengkapi dengan desain pembelajaran, selanjutnya akan dilakukan uji validasi pakar. Uji validasi ini bertujuan untuk dapat mengetahui kelebihan dan kelemahan model secara konseptual menurut para ahli, ketentuan teori yang akan digunakan, sehingga didapatkan kesesuaian dari isinya. Validasi ini melibatkan dua orang validator yang terdiri dari 1 orang ahli desain pembelajaran dan 1 orang ahli media pembelajaran.

Analisis data hasil uji coba lapangan terbatas menggunakan pengujian dengan teknik Uji Man Whitney $U$ Test membandingkan hasil pretest dan posttest. Kemudian untuk Angket respon guru dan siswa berguna untuk mengetahui tingkat keterimaan guru dan siswa terhadap produk yang dikembangkan dalam penelitian ini.

\section{HASIL DAN PEMBAHASAN}

Hasil studi pendahuluan tentang kebutuhan modell diperoleh kesenjangan yang ditemui dari sekolah yaitu bahwa siswa kelas 3 mengalami kesulitan dipelajaran IPA khsusnya materi gerak benda. Guru terlihat belum menggunakan metode pembelajaran bervariasi yang sesuai dengan rambu-rambu pembelajaran IPA, guru cenderung menggunakan metode ceramah, tanya jawab, dan diskusi. Dalam kegiatan pembelajaran guru juga belum menggunakan teknologi informasi dan komunikasi (TIK) sebagai media pembelajaran. Padalah kegiatan pembelajaran seharusnya berpusat pada siswa (student center).

Berpijak pada kesenjangan diatas maka dilakukan pengembangan model pembelajaran Guidif.. Pengembangan model pembelajaran Guidif mengacu pada rumusan masalah yaitu: 1) bagaimana model pembelajaran Guidif dapat meningkatkan hasil belajar IPA kelas 3 ; 2) seberapa tinggi tingkat validitas produk model pembelajaran Guidif untuk meningkatkan hasil belajar IPA kelas 3; apakah hasil pembelajaran menggunakan model pembelajaran Guidif lebih tinggi dari sebelum menggunakan model pembelajaran Guidif. Pengembangan model pembelajaran Guidif dikembangkan dengan model pengembangan ASSURE yang terdiri dari 6 tahap. Berikut adalah uraian tentang pengembangan Guidif yang lebih rinci.

\section{Analyze Leaner Characteristic}

Pada tahap ini dilakukan wawancara, obervasi dan studi dokumen kepada guru dan siswa kelas 3 di SDN Anggrasmanis Kabupaten Karanganyar. Dari hasil wawancara dijumpai masalah bahwa guru terlihat belum menggunakan metode pembelajaran bervariasi yang sesuai dengan rambu-rambu pembelajaran IPA, guru cenderung menggunakan metode ceramah, tanya jawab, dan diskusi sehingga bisa dikatakan guru hanya menggunakan metode yang cenderung sama. Dalam kegiatan pembelajaran guru juga belum menggunakan teknologi informasi dan komunikasi (TIK) sebagai media pembelajaran, sehingga proses pembelajaran cenderung monoton. Padalah kegiatan pembelajaran seharusnya berpusat pada siswa (student center). Untuk mencapai keberhasilan dalam pembelajaran hendaknya guru menggunakan model pembelajaran yang sesuai dengan rambu IPA dan media Pembelajaran.

\section{State Objectives}

Kurikulum yang digunakan dalam pengembangan model pembelajaran Guidif adalah kurikulum 2006 (KTSP) pelajaran IPA kelas 3 SD semester genap tahun pelajaran 2017/2018 dengan SK (Standar Kompetesi) memahami berbagai cara gerak benda, hubungannya dengan energi, dan sumber energi yang dibagi menjadi lima kompetensi dasar. Kemudian dipilih kompetensi dasar pertama yaitu menyimpulkan hasil pengamatan bahwa gerak benda dipengaruhi oleh bentuk dan ukuran. Indikator berdasarkan materinya yaitu:

a. Menjelaskan berbagai macam gerak benda.

b. Menyebutkan faktor-faktor yang mempengaruhi gerak benda.

c. Menentukan berbagai contoh gerak benda.

\section{Select, Modify, or Design Materials}

Tahap ini menentukan model pembelajaran serta media yang sesuai untuk mengatasi masalah yang dihadapi SDN 01 Anggrasmanis Kabupaten Karanganyar khususnya pada mata pelajaran IPA. Model pembelajaran yang sesuai dan dipilih untuk mengatasi masalah IPA yaitu model pembelajaran Guided Discovery. Kemudian dipilih media pembelajaran yang memanfaatkan TIK yang dinamai Media Interaktif.

\section{Utilize Media and Materials}

Pada tahap ini yaitu tahap dikembangkannya produk berupa silabus, RPP, dan media. Tahap ini juga akan dipaparkan hasil validasi pakar media dan desain pembelajaran guna mengetahui tingkat kelayakan media dan desain pembelajaran yang dikembangkan. Selain itu akan dipaparkan juga hasil dari validitas dan reliabilitas soal pretest dan soal posttest uji coba terbatas atau penelitian. Setelah pengujian instrumen soal pretest di SDN 01 Balong di dapat hasil untuk pretest yaitu dari 30 soal yang di ujikan setelah lakukan uji validitas dan reliabilitas menggunakan software SPSS for Windows versi 20 sebanyak 13 soal yang valid atau item soal yang nilai Corrected Item-Iotal Correlation $\geq 0,300$ dan untuk tingkat reliabilitas atau Cronbach's Alpha yaitu 
sebesar 0,687 dan hasil ini lebih tinggi dari acuan yang ditentukan yaitu $\alpha \geq 0,600$ sehingga instrumen soal ini dapat dikatakan reliabel. Selanjutnya untuk soal posttest setelah 30 soal diujikan kepada siswa, sebanyak 12 soal yang valid atau yang nilai Corrected Item - Total Correlation $\geq 0,300$. Selanjutnya untuk tingkat reliabilitas atau Cronbach's Alpha soal posttest ini yaitu sebesar 0,727 yang berarti lebih besar dari 0,600 yang artinya soal ini reliabel.

\section{Pelaksanaan Uji Coba Terbatas}

Tahap ini juga merupakan tahap penggunaan dengan kata lain tahap pelaksanaan uji coba lapangan terbatas. Uji coba terbatas ini akan dilaksanakan setelah dilakukan validasi pakar terhadap desain pembelajaran dan media. Uji coba terbatas akan dilakukan kepada 23 siswa kelas 3 SD. Uji coba terbatas ini hari Jum'at 16 Maret 2018. Data yang diperoleh dari uji coba terbatas ini yaitu berupa hasil tes siswa, angket respon siswa, angket respon guru, dan lembar observasi guru kelas 3.

\section{Require learner participation}

Tahap ini dilaksanakan pembelajaran, siswa akan lebih banyak belajar secara mandiri dan melalui kegiatan praktik yang melibatkan komputer. Siswa akan dibentuk secara berkelompok dalam mengoperasikan media pembelajaran yang dikembangkan. Dalam kelompok itu siswa akan diberi tugas yaitu menjawab pertanyaan yang berkaitan dengan media pembelajaran. Selain itu siswa secara bergantian dapat mencoba media pembelajaran yang telah disediakan.

\section{Evaluate}

Tahap ini yaitu tahap evaluasi dan merevisi, pembelajaran berhasil dilaksanakan dalam penelitian ini. Hasil dari uji coba terbatas dengan menggunakan model pembelajaran Guidif. Pengukuran kompetensi hasil belajar siswa menghasilkan data rata-rata nilai pretest mencapai 63,70, dan rata-rata nilai posttest mencapai 79 . Setelah diketahui rata-rata hasil pretest dan posttest akan dilakukan perhitungan komparasi rata-rata dengan menggunakan perhitungan Gain Skor, yang diperoleh hasil sebesar 15 .

Kemudian dilihat dari tingkat siginifikasinnya diperoleh nilai $U$ sebesar 96 dengan memiliki taraf signifikansinya sebesar $\alpha$ o,oo. Oleh karena $\alpha, 0,00<\alpha=$ 0,050, maka dampak dari variabel independen model pembelajaran Guidif pada variabel dependen signifikan. Artinya bahwa kompetensi hasil tes menggunakan

\section{Hasil Uji Pakar}

Uji pakar atau uji ahli digunakan untuk mengukur tingkat kelayakan media dan desain pembelajaran yang merupakan hasil produk dari pengembangan ini yang nantinya akan diuji cobakan. Lembar penilaian dari komponen yang di nilai yaitu RPP meliputi 20 butir penilaian. Berdasarkan hasil penilaian yang telah didapat dari validator pada aspek desain pembelajaran memperoleh skor persentase sebesar 80\%. Kriteria persentase tersebut tergolong dalam kategori "Sangat
Tinggi” sehingga dapat dikatakan layak untuk digunakan. Sedangkan untuk validator pada aspek media memperoleh skor persentase $90 \%$, dan sesuai dengan kriteria yang telah ditentukan termasuk ke dalam kategori "Sangat Tinggi".

\section{Hasil Uji Validitas dan Reliabilitas Soal Pretest dan Posttest}

Uji coba validitas dan reliabilitas dilakukan kepada siswa kelas 3 SDN 01 Anggrasmanis Kecamatan Jenawii Kabupaten Karanganyar dengan jumlah 23 siswa dan bukan merupakan SD yang akan digunakan untuk Model Pembelajaran Guidif lebih tinggi bila dilihat secara signifikan sebelum menggunakan Model Pembelajaran Guidif.

Kemudian tingkat keterimaan guru dari hasil penyebaran angket respon guru dan siswa yaitu, respon guru yang terdiri dari 8 pernyataan memperoleh skor secara keseluruhan yaitu 35 dan dengan persentase $87,5 \%$ sehingga tergolong ke dalam kategori "Sangat Baik". Sedangkan hasil angket respon siswa memperoleh persentase sebesar 92,96\% dalam kategori "Baik".

Keefektifan pada setiap langkah pengembangan model ini sejalan dengan pandangan Smaldino, dkk (2011,109) yang menyatakan bahwa model ASSURE merupakan salah satu model yang mampu digunakan untuk menentukan pembelajaran secara sistematis dalam merencanakan proses pembelajarn secara efektif. Berdasarkan hasil pembahasan penelitian yang dilakukan, penelitian ini mendukung penelitian yang relevan dari I Putu Yogy Adi Pradipta .2014. berjudul "Pengembangan Media Pembelajaran IPA Terhadap Siswa Kelas VII SMPN 1 Pupuan Semester Genap Tahun 2013/1014". Media pembelajaran yang digunakan dalam penelitian ini berbantuan Software Adobe Flash CS6. Hasil penelitian menunjukkan bahwa hasil uji ahli isi yaitu $96 \%$ berada pada kualitas sangat baik. Asil uji ahli desain sebesar 90\% berada pada kualitas sangat baik. Hasil uji ahli media sebesar $88,3 \%$ berada pada kualitas baik. Hasil uji perorangan sebesar 95,33\% berada pada kualitas sangat baik. Hasil uji kelompok kecil sebesar 94,33\% berada pada kualitas sangat baik. Hasil uji lapangan sebesar 93,4 \% berada pada kualitas sangat baik.

Penelitian lain yang sejalan dengan penelitian yang dilakukan penulis bukan hanya berkaitan dengan satu komponen saja yaitu Model Pembelajaran Guidif. Melainkan komponen lain yaitu model pembelajaran Guided Discovery (penemuan terbimbing) juga perlu diperhatikan. Penelitian ini sejalan yang dilakukan oleh Dian Wijayanti .2016. berjudul " Pengembangan Perangkat Pembelajarann Statistika dan Peluang dengan Metode Penemuan Terbimbing Berorientasi Kurikulum 2013 untuk Siswa Kelas X". Hasil penelitian menunjukkan bahwa dengan menggunakan model pembelajaran penemuan terbimbing dapat meningkatkan hasil belajar. 


\section{SIMPULAN DAN SARAN}

Berdasarkan hasil penelitian dan pembahasan, dapat ditarik kesimpulan antara lain:

1. Model pembelajaran Guidif dapat dikembangkan menggunakan desain pengembagan ASSURE (analyze learners, state objectives, select method, media or materials, ultilize media and materials, require leraners participation, evaluate and revise).

2. Tingkat validitas model pembelajaran Guidif setelah mendapatkan penilaian dari ahli desain pembelajaran mencapai 80\% dengan kategori sangat tinggi, validasi ahli media sebesar 90\% dengan kategori sangat tinggi.

3. Hasil pembalajaran menggunakan model Guidif lebih tinggi dari sebelum menggunkan model Guidif. Simpulan ini didasarkan pada skor pretes mencapai $63,7 \%$ dan $79 \%$ untuk skor postest. Dilihat dari signifikansi dari uji U, terlihat nila uji U sebesar 96 dengan memiliki taraf signifikansinya sebesar a o,oo. Oleh karena $\alpha 0,00<\alpha=0,050$.

\section{Saran}

Berdasarkan simpulan hasil penelitian dan pengembangan Model Pembelajaran Guidif diatas, berikut disampaikan saran untuk menindak lanjuti pengembangan model ini agar lebih berkualitas sehingga dapat digunakan dalam proses pembelajaran, antara lain: Bagi Siswa

Model Pembelajaran Guidif yang dikembangkan mempermudah siswa dalam memahami materi gerak benda. Siswa lebih semangat untuk belajar karena materi disampaikan dengan lebih menarik. Siswa juga lebih mudah dalam memahami materi, hal ini terbukti karena di dalam media interaktif terdapat materi, quiz dan games yang dapat membantu siswa dan hasil belajar siswa juga meningkat. Siswa juga terlihat mandiri karena siswa sudah bisa belajar dengan mengggunakan media interaktif tanpa harus dibantu guru satu per satu saat pembelajaran berlangsung.

Bagi Guru: Model Pembelajaran Guidif dapat dijadikan sebagai referensi bagi guru. Model Pembelajaran Guidif juga dapat dijadikan sebagai media pembelajaran oleh guru untuk menyempurnaan materi gerak benda.

Bagi Sekolah: Model Pembelajaran Guidif dapat dijadikan sebagai referensi dan bahan ajar untuk kegiatan belajar siswa. Dapat juga sebagai wacana dalam meningkatkan upaya guru dalam meningkatkan mutu pengajaran dan hasil pembelajaran.

Bagi Peneliti Selanjutnya: Pengembangan model pembelajaran Guidif (Guided Discovery dengan media interaktif) dapat dikembangkan lebih baik lagi, dan dapat menjadi inspirasi dan sumber referensi saat melakukan penelitian selanjutnya.

\section{UCAPAN TERIMA KASIH}

Dengan ini penulis mengucapkan terimakasih kepada Ibu Dr. Henny Dewi Koeswati, M.Pd dan Ibu Sri Giarti, S.Pd., M.Pd yang telah membimbing dan memberi arahan sehingga penulis dapat menyelesaikan tugas akhir dengan baik.

\section{DAFTAR RUJUKAN}

[1] Abrani, N. A. (2012). Pengaruh Penerapan Metode Pembelajaran Guided Discovery Terhadap Keterampilan Proses Sains Siswa Kelas X SMA Negeri 1 Teras Boyolali Tahun Pelajaran 2011/2012. Jurnal Pendidikan Biologi. Vol 4, No 2, (16)

[2] Arsyad, Azhar. 2013. Media Pembelajaran. Jakarta: Rajawali Press

[3] Agus, S. (2013). Strategi Pembelajaran Teori \& Aplikasi. Jogjakarta: Pustaka Pelajar.

[4] Gagne, Robert, M., \& Leskic, J. B. (1970). Principle of Instructional Design. Harcount Brace Jovanivich College: San Diego.

[5] Hujair, A. S. (2013). Media Pembelajaran Interaktifinovatif. Yogyakarta: Kaukaa Dipantara.

[6] I Putu, Y. A. (2014). Pengembangan Media Pembelajaran IPA Terpadu Siswa Kelas VII SMPN 1 Pupuhan Semester Genap Tahun 2013/2014. e-Journal Edutect Universitas Pendidikan Ganesha.Vol 2, No 1 (2)

[7] Indah, S. S. (2014). Pengembangan Permainan Tradisional Jamuran Sebagai Media Pembelajaran Tata Nama Senyawa di Kelas X SMA. Unesa Journal of Chemical Education.Vol 3, No 2, (280)

[8] Mawardi. (2014). Model Desain Pembelajaran Konsep Dasar PKn Berbasis Belajar Mandiri Menggunakan Moodle. Salatiga: Widya Sari Press.

[9] Mohammad, Y. (2012). E-Learning Sebagai Media Pembelajarn Interaktif Berbasis Teknologi Informasi. Jurnal Ilmiah Foristek. vol 2, No 1, (144-145)

[10] Nana, S. S. (2015). Metode Penelitian Pendidikan. Bandung: PT Remaja Rosdakarya.

[11] Nasional, D. P. (2004). Kurikulum Pendidikan Dasar. Jakarta.

[12] Peraturan Menteri Pendidikan Nasional Republik Indonesia Nomor 22. Tahun 2006 Tentang Standar isi. 2006 Jakarta.:BNSP

[13] Peraturan Menteri Pendidikan Nasional Republik Indonesia Nomor 16. Tahun 2007 Tentang Standar Kualitas akademik dan Kompetensi Guru. 2007.Jakarta.:BNSP

[14]Rusman. (2012). Model-Model Pembelajaran : Mengembangkan Profesionalisme Guru. Depok: PT Rajagrafindo Persada. 


\section{BIOGRAFI PENULIS}

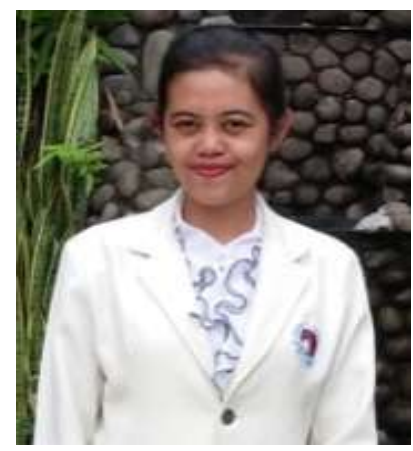

Penulis bernama lengkap "Yulius Kristini". Lahir dii Dusun Polan 02/05 Desa Menjing Kecamatan Jenawii Kabupaten Karanganyar Provinsi Jawa Tengah pada tanggal 02 Juli 1995 dari pasangan Suyarmo dan Sujiyem. Penulis adalah anak pertama dari 2 bersaudara. Pendidikan sekolah dasar dimulai dari SDN o1 Menjing Kecamatan Jenawi pada tahun 2002 - 2008. Setelah itu melanjutkan pendidikan sekolah menengah ke SMPN o1 Jenawi pada tahun 2008 - 2011 dan terakhir di SMKN Jenawii pada tahun 2011 - 2014. Kemudian penulis melanjutkan pendidikan di Pendidikan Guru Sekolah Dasar Universitas Kristen Satya Wacana Salatiga 2014 sampai sekarang. Kritik, saran, maupun hal-hal yang berkaitan dengan kelanjutan atau pengembangan dari hasil penelitian ini bisa dikirim ke email penulis di:

yuliuskristini13@gmail.com 